\title{
Stable oxygen isotope record of the Eocene-Oligocene transition in the southern North Sea Basin: positioning the Oi-1 event
}

\author{
E. De Man ${ }^{1}$, L. Ivany ${ }^{2} \&$ N. Vandenberghe ${ }^{3}$
}

1 Royal Belgian Institute of Natural Sciences, Vautierstraat 29, B-1000 Brussels, Belgium Ellen.DeMan@naturalsciences.be (corresponding author)

2 Department of Earth Sciences, Syracuse University, Syracuse, New York 13244, USA

3 Historical Geology, K.U. Leuven, Redingenstraat 16, B-3000 Leuven, Belgium

Manuscript received: February 2004; accepted: August 2004

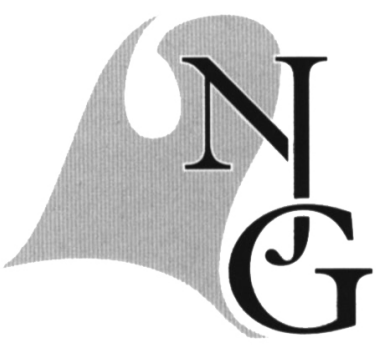

\begin{abstract}
Preliminary stable oxygen isotope data are presented from the southern North Sea Basin successions, ranging from the Lutetian to Rupelian. Analyses were performed on fish otoliths, nuculid bivalves and benthic foraminifera and are presented as bulk $\delta^{18} \mathrm{O}$ values relative to a well established regional sequence stratigraphic framework. The most significant positive shift in $\delta^{18} \mathrm{O}$ values clearly falls at the top of the regionally recognised Bassevelde 3 sequence, which base corresponds to the Eocene-Oligocene GSSP boundary. The here documented $\delta^{18} \mathrm{O}$ shift is closely associated with the base of the traditional Rupelian unit-stratotype and is tentatively correlated to the globally recognised Oi-1 event.
\end{abstract}

Keywords: Eocene-Oligocene boundary, stable isotopes, Oi-1 event, sequence stratigraphy

\section{Introduction}

As a proxy for earth's changing climate, $\delta^{18} \mathrm{O}$ curves have been established for different regions all over the world. At the Eocene-Oligocene transition, several notable positive excursions in the curve have been recognised, mostly based on data from the open ocean (e.g., Zachos et al., 1996, 2001; Miller et al., 1991, 1998; Abreu \& Anderson, 1998; Bohaty \& Zachos, 2003). Beginning in the basal Oligocene, oxygen isotope values of marine carbonates become significantly more positive than those of the late Eocene. The earliest and largest magnitude shift has been termed the Oi-1 event, and occurred between 33.5 and $33.05 \mathrm{Ma}$ (Zachos et al., 1996), slightly later than the EoceneOligocene boundary at $33.7 \mathrm{Ma}$ (Odin \& Montanari, 1989 ). Although the primary cause of this $\delta^{18} \mathrm{O}$ shift remains controversial (e.g., Lear et al., 2000), its global character is widely accepted and can thus be applied to resolve stratigraphic problems around that crucial time interval.

The southern North Sea Basin (Fig. 1) is of particular stratigraphic interest, because it is home of several unit-stratotype sections of the Paleogene, such as the Rupelian Stage which has been defined in the Boom Formation in northern Belgium (Dumont, 1849). Although the regional stratigraphic framework of this region is well constrained, correlation to the international time scale is often hampered around the Eocene-Oligocene interval because of the absence of time-indicative calcareous index fossils. The base of the Rupelian unit-stratotype has been correlated to the Massignano section in central Italy by means of organic walled dinoflagellate cysts (Stover \& Hardenbol, 1994; Brinkhuis \& Visscher, 1995) and proved to coincide with a level well above the EoceneOligocene Global boundary Stratotype Section and Point (GSSP). Vandenberghe et al. (2003) incorporated 

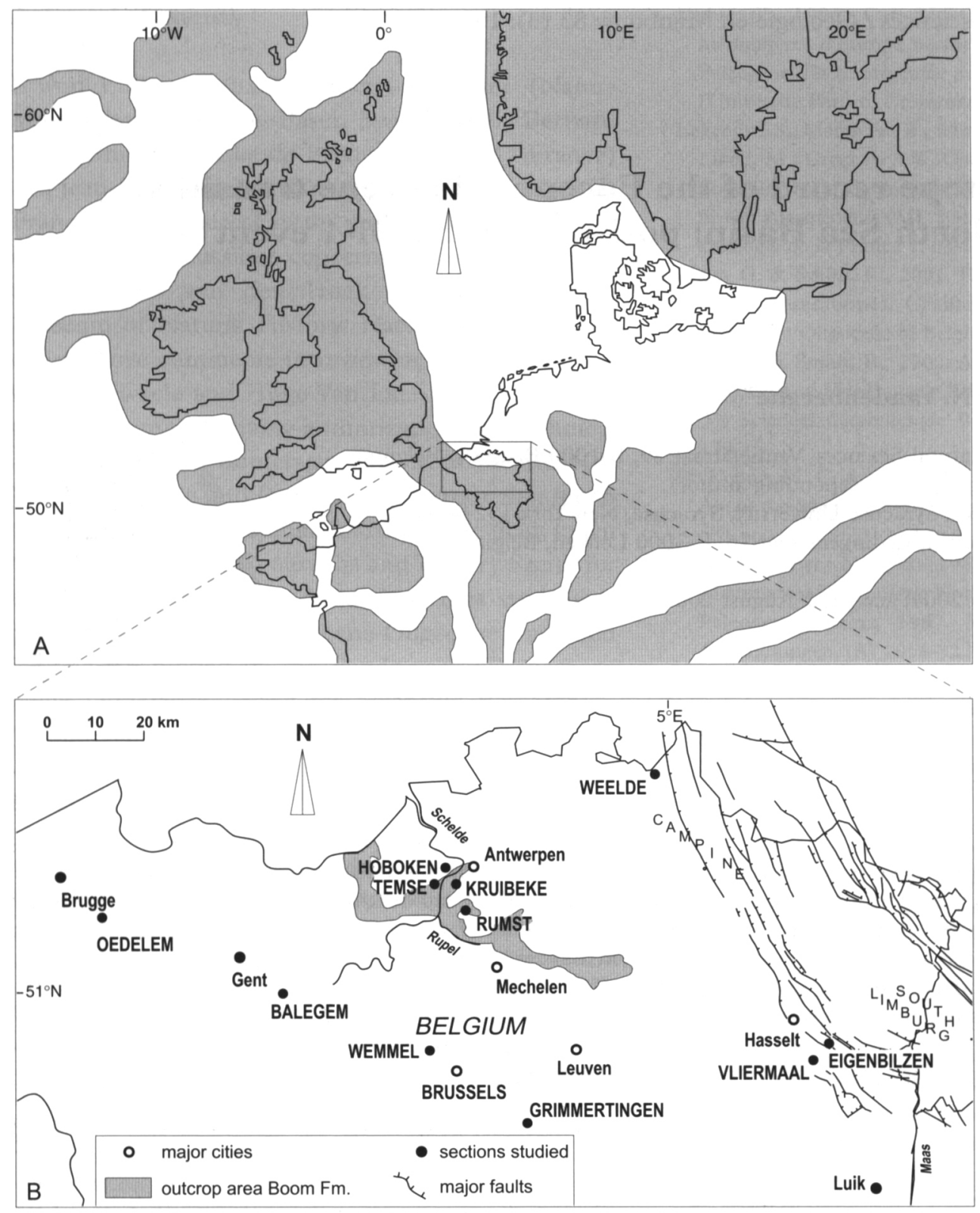

Fig. 1. A. Paleogeographic map of northwest Europe during Rupelian times. Shaded areas indicate land, white areas marine conditions. (Modified after Ziegler, 1990; Sissingh, 2003). Coordinates represent present day UTM coordinates. B. Location of studied sections.

these results into a regional sequence stratigraphic framework and indicated that the Eocene-Oligocene GSSP correlates with a level between the Bassevelde 2 and Bassevelde 3 sequences, whereas the base of the Rupelian unit-stratotype belongs to the younger Boom sequence (see Fig. 2).

Isotopic studies on the North Sea Basin are limited (e.g., Buchardt, 1978; Schmitz et al., 1996) and have never been applied in stratigraphic problems for the time interval discussed in this paper. The goal of this preliminary study is to document the $\delta^{18} \mathrm{O}$ signal of the Eocene-Oligocene deposits in the southern North Sea Basin, compare it to the globally recognised Oi-1 event, and to evaluate its position in respect to the Eocene-Oligocene GSSP and the regional sequence stratigraphic framework.

\section{Geological setting}

During the terminal Eocene and transition to the Oligocene, northern Belgium occupied the southernmost part of the Cenozoic North Sea Basin (Fig. 1) and today provides a well documented reference shelf section for that time interval. The Lower Oligocene Rupelian Stage has originally been defined in the stiff clays cropping out along the river Rupel in northern Belgium (Fig. 1), nowadays lithostratigraphically referred to as the Boom Formation (Fig. 2). Recent sequence stratigraphic studies distinguish four depositional sequences within the Eocene-Oligocene transitional interval (Bassevelde 1,2 and 3 and Boom 1 sequence; NP18-NP23; Vandenberghe et al., 2003) and interpret the Boom Formation as part of a second 


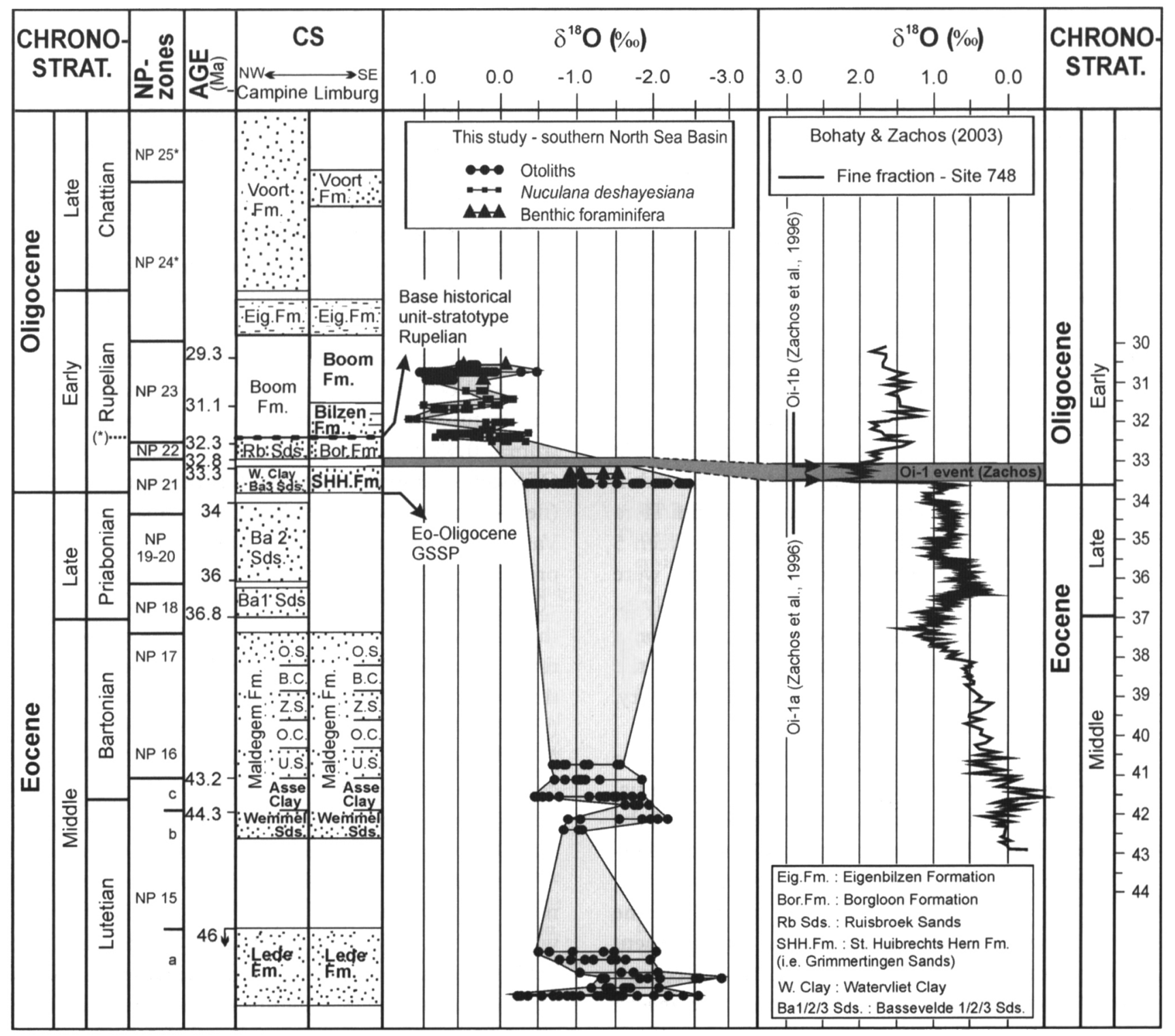

Fig. 2. Positioning of the Oi-1 isotope event of Zachos et al. (1996) within the southern North Sea Basin composite section, by calibration with the Bohaty \& Zachos (2003) oxygen isotope curve. Formations and Members that were sampled in this study are indicated in bold in the composite section (CS). $\left({ }^{\star}\right)$ marks the base of the traditional Rupelian Stage; note the discrepancy with the official Eocene-Oligocene boundary GSSP. The Bassevelde 3 sequence corresponds to the marine tongrian deposits. Calcareous nannoplankton zonation for the lower part of the section after Steurbaut (1992), for the upper part after Van Simaeys et al. (2004). A summary of all age calibration methods is given in Van Simaeys et al. (2004) and dates are given according to Berggren et al. (1995).

Oligocene sequence that starts at the base of the underlying Ruisbroek Sand Member. The older Bassevelde 3 depositional sequence hence makes up the first Oligocene sediments within the North Sea Basin. These insights result from detailed biostratigraphical correlations by means of dinoflagellates (Stover \& Hardenbol, 1994; Brinkhuis \& Visscher, 1995), showing that the exact position of the EoceneOligocene boundary as defined by the GSSP in Massignano (Central Italy) falls at the base of the Bassevelde 3 sequence, well below the base of the traditional Rupelian unit-stratotype (Fig. 2; Vandenberghe et al., 2003).
The age of the North Sea Basin section is established based on detailed bio- and sequence stratigraphy, and is further constrained by magnetostratigraphic and geochemical anchor points (Stover \& Hardenbol, 1994; Brinkhuis \& Visscher, 1995; Vandenberghe et al., 2001, 2003; Van Simaeys et al., 2004; Lagrou et al., 2004). Appropriate age data for these anchor points as calibrated by Berggren et al. (1995) are summarized in Fig. 2. 


\section{Materials and Methods}

Fish otoliths (ear stones, mainly from the family Congridae), nuculid bivalves (Nuculana deshayesiana), and benthic foraminifera (Cibicidoides spp. and nodosariids) from the above mentioned units were selected for analysis from core and outcrop samples in the southern North Sea Basin (Fig. 1) based on their size and quality of preservation. Otoliths and bivalves were sectioned and polished to reveal fresh aragonite within, and sample trajectories were drilled perpendicular to the axis of growth in pristine portions of the structures with a Merchantek MicroMill so as to subsume any intra-annual variation within the sample and thereby derive overall average bulk compositions. Three to five samples were collected in this manner from each specimen. Benthic foraminifera were prepared as in Thomas et al. (2000). Between 5 and 50 cleaned specimens from each sample were crushed and pieces of test calcite selected for analysis. Stable oxygen isotope analyses were performed on a Finnigan MAT 251 mass spectrometer at the University of Michigan Stable Isotope Laboratory, and are reported relative to the VPDB standard.

56 fish otoliths, 14 nuculid bivalves, and 10 benthic foraminiferan samples were analyzed for this initial investigation. While otoliths provide the bulk of the data upon which this present analysis is based, wherever possible we have selected and sampled otolith, bivalve, and foraminiferan carbonate from the same sample horizons in order to enable the establishment of inter-taxon calibrations for use in future compilations. This will allow the extension of our record into the subsurface using borehole samples dominantly consisting of foraminifera, and across stratigraphic intervals in outcrop where only one of the three groups is present. In this manner, a more complete geochemical record can be generated from the middle Eocene through the Oligocene (De Man et al., in preparation).

A composite section (CS) was constructed ranging from the Middle Eocene to Lower Oligocene in order to represent the sampled interval (Fig. 2). The correlation between the fully marine sediments of the Campine area (northern Belgium) and the more marginal marine sediments of the Limburg area (central to northeast Belgium) is based on geophysical well log correlation (Vandenberghe et al., 2001, 2003) combined with calcareous nannoplankton (Steurbaut, 1992) and organic walled dinoflagellate (De Coninck, 2001) biostratigraphy. At present, no upper Eocene samples are included due to a lack of available outcrops; however we expect to remedy this deficiency using borehole samples in future analyses.

\section{Results and discussion}

The resulting $\delta^{18} \mathrm{O}$ values from all taxa are plotted in Fig. 2, relative to the VPDB standard. No correction factors have yet been established and thus bulk data are compared to fine fraction analyses of Bohaty \& Zachos (2003). Since no detailed curve has yet been established for shelf sections for the studied interval (Lutetian to Rupelian), our results are best compared to $\delta^{18} \mathrm{O}$ variations within the surface waters of the open ocean.

$\delta^{18} \mathrm{O}$ values show a clear distinction between the middle Eocene and lower Oligocene samples, the former ranging from $-2.5 \%$ to $-0.5 \%$ and the latter from $-0.5 \%$ to $+1 \%$ (Fig. 2). The lowermost Oligocene samples from the Grimmertingen Sands (near-shore equivalent of Bassevelde 3 sequence, see Vandenberghe et al., 2003, fig. 24.7) still show prevailing low $\delta^{18} \mathrm{O}$ values, ranging from $-2.5 \%$ to $-0.5 \%$. Hence, the main $\delta^{18} \mathrm{O}$ shift clearly falls above the Bassevelde 3 sequence, near the base of the traditional Rupelian Stage (or second Oligocene depositional sequence according to Vandenberghe et al., 2003) (Fig. 2). Seen the magnitude of the observed $\delta^{18} \mathrm{O}$ shift $(\sim 1.5 \%)$ and its stratigraphic position, it is believed to correspond to the Oi-1 event observed in the open ocean (comprising the Oi- $1 \mathrm{a}$ and Oi-1b of Zachos et al., 1996, Fig. 4, 6; Bohaty \& Zachos, 2003).

It is unlikely that these results are biased toward more negative values by either diagenesis or freshwater influx. The Grimmertingen Sands have not suffered any significant diagenetic alteration, as shown by the unconsolidated nature of the sands and the preservation of original aragonite within the fossils. In addition, the presence of glauconite clearly points towards a marine origin of the sands, while the enclosed fossils give evidence for shelf conditions well below wave influence, away from potential estuarine areas (Winkelmolen, 1972; Vandenberghe et al., 1998, p. 141-144). Unless the entire basin suffered from brackish conditions, it is unlikely that the negative $\delta^{18} \mathrm{O}$ values can be explained by mixing with fresh water. Geochemical evidence from $8^{13} \mathrm{C}$ or ${ }^{86} \mathrm{Sr} /{ }^{87} \mathrm{Sr}$ is not yet available to unequivocally confirm these findings, but will be considered in future initiatives.

\section{Conclusions}

Preliminary oxygen isotope data from the well calibrated southern North Sea Basin successions indicate that the most significant positive shift in $\delta^{18} \mathrm{O}$ values (correlated to the Oi-1 event of Zachos et al., 1996) is situated well within the Oligocene if calibrated against the Eocene-Oligocene GSSP. This study 
proves that the Oi-1 event falls above the Bassevelde 3 sequence and is thus closely associated with the base of the traditional Rupelian unit-stratotype.

\section{Acknowledgements}

Dirk Nolf is thanked for providing otolith samples and helping with identifications. Many thanks go to Lora Wingate for providing isotope analyses and to Frans Moorkens for all-round technical support. We are indebted to Stefaan Van Simaeys and Etienne Steurbaut for fruitful discussions. Dr. Ellen Thomas is gratefully acknowledged for a detailed review of the paper. This work was supported by FWO-Flanders (research grant G.0093.01). EDM acknowledges the support of the DWTC-Brussels (Grant WI/36/C03).

\section{References}

Abreu, V.S. \& Anderson, J.B., 1998. Glacial eustasy during the Cenozoic: sequence stratigraphic implications. AAPG Bulletin, 82(7): 1385-1400.

Berggren, W.A., Kent, D.V., Swisher, I., C.C. \& Aubry, M.-P., 1995. A revised Cenozoic geochronology and chronostratigraphy. In: W.A. Berggren, D.V. Kent, M.-P. Aubry and J. Hardenbol (Editors), Geochronology, time scales and global stratigraphic correlation. Special Publication 54. Society of Economic Paleontologists and Mineralogists (Tulsa): 129-212.

Bohaty, S. \& Zachos, J.C., 2003. Significant Southern Ocean warming event in the late middle Eocene. Geology 31(11): 1017-1020.

Brinkhuis, H. \& Visscher, H., 1995. The upper boundary of the Eocene series: a reappraisal based on dinoflagellate cyst biostratigraphy and sequence stratigraphy. In: W.A. Berggren, D.V. Kent, M.-P. Aubry \& J. Hardenbol (eds), Geochronology, time scales and global stratigraphic correlation. Special Publication 54. Society of Economic Paleontologists and Mineralogists (Tulsa): 295-304.

Buchardt, B., 1978. Oxygen isotope palaeotemperatures from the Tertiary period in the Norh Sea area. Nature 275: 121-123.

De Coninck, J., 2001. Organic-walled microfossils in the Oligocene Grimmertingen and Neerrepen Sand Members from the Grimmertingen type locality. Professional Paper 294(2): 1-57.

Dumont, A., 1849. Rapport sur la carte géologique de la Belgique. Bulletin de l'Académie royale de Belgique, XVI(11): 351-373.

Lagrou, D., Vandenberghe, N., Van Simaeys, S. \& Hus, J., 2004. Magnetostratigraphy and rock magnetism of the Boom Clay (Rupelian stratotype) in Belgium. Netherlands Journal of Geosciences / Geologie en Mijnbouw 83(3): 209-225.

Lear, C.H., Elderfield, H. \& Wilson, P., 2000. Cenozoic deep-sea temperature and global ice volumes from $\mathrm{Mg} / \mathrm{Ca}$ in benthic foraminiferal calcite. Science 287: 269-272.

Miller, K.G., Feigenson, M.D., Wright, J.D. \& Clement, B.M., 1991. Miocene isotope reference section, Deep Sea Drilling Project site 608: an evaluation of isotope and biostratigraphic resolution. Paleoceanography 6(1): 33-52.

Miller, K.G. Mountain, G.S., Browning, J.V., Kominz, M., Sugarman, P.J., Christy-Blick, N., Katz, M.E. \& Wright, J.D., 1998. Cenozoic global sea level, sequences, and the New Jersey transect: results from coastal plain and continental slope drilling. Reviews of Geophysics 36(4): 569-601.
Odin, G.S. \& Montanari, A., 1989. Age radiométrique et stratotype de la limite Eocène Oligocène. Comptes Rendus de l'Académie des Sciences de Paris, série II, 309: 1939-1945.

Schmitz, B., Heilmann-Clausen, C., King, C., Steurbaut, E., Andreasson, F.P., Corfield, R.M. \& Cartlidge, J.E., 1996. Stable isotope and biotic evolution in the North Sea during the early Eocene; the Albaek Hoved section, Denmark. In: R.W.O.B. Knox, R.M. Corfield and R.E. Dunay (eds), Correlation of the early Paleogene in Northwest Europe. Geological Society of London, Special Publication 101: 275-306.

Sissingh, W., 2003. Tertiary paleogeographic and tectonostratigraphic evolution of the Rhenish Triple Junction. Palaeogeography, Palaeoclimatology, Palaeoecology 196: 229-263.

Steurbaut, E., 1992. Integrated stratigraphic analysis of lower Rupelian deposits (Oligocene) in the Belgian Basin. Annales Société Geologie Belgique 115(1): 287-306.

Stover, L.E. \& Hardenbol, J., 1994. Dinoflagellates and depositional sequences in the Lower Oligocene (Rupelian) Boom Clay Formation, Belgium. Bulletin de la Société belge de Géologie 102(1-2): 5-77.

Thomas, E., Zachos, J.C. \& Bralower, T.J., 2000. Deep-sea environments on a warm earth: latest Paleocene-early Eocene. In: B.T. Huber, K.G. Macleod \& S.L. Wing (eds), Warm Climates in Earth History. University Press, Cambridge UK (Cambridge): 132-160.

Van Simaeys, S., De Man, E., Vandenberghe, N., Brinkhuis, H. \& Steurbaut, E., 2004. Stratigraphic and palaeoenvironmental analysis of the Rupelian-Chattian transition in the type region: evidence from dinoflagellate cysts, foraminifera and calcareous nannofossils. Palaeogeography, Palaeoclimatology, Palaeoecology 208: 31-58.

Vandenberghe, N., Brinkhuis, H. \& Steurbaut, E., 2003. The Eocene/Oligocene boundary in the North Sea area: a sequence stratigraphic approach. In: D.D. Prothero, L.C. Ivany \& E.A. Nesbitt (eds), From Greenhouse to Icehouse. The Marine Eocene-Oligocene Transition. Columbia University Press (New York): 419-437.

Vandenberghe, N., Hager, H., Van Den Bosch, M., Verstraelen, A., Leroi, S., Steurbaut, E., Prüfert, J. \& Laga, P., 2001. Stratigraphic correlation by calibrated well logs in the Rupel Group between North Belgium, the Lower-Rhine area in Germany and Southern Limburg and the Achterhoek in The Netherlands. In: N. Vandenberghe (ed), Contributions to the Paleogene and Neogene Stratigraphy of the North Sea Basin. Aardkundige Mededelingen 11. Leuven University Press (Leuven): 69-84.

Vandenberghe, N., Laga, P., Steurbaut, E., Hardenbol, J. \& Vail, P.R., 1998. Tertiary sequence stratigraphy at the Southern border of the North Sea basin in Belgium. In: P.-C. de Graciansky, J. Hardenbol, T. Jacquin \& P.R. Vail (eds), Mesozoic and Cenozoic sequence stratigraphy of European Basins. SEPM (Society for Sedimentary Geology), Tulsa, Oklahoma, U.S.A.: 119-153.

Winkelmolen, A.M., 1972. Shape sorting in Lower Oligocene, Northern Belgium. Sedimentary Geology, 7: 183-227.

Zachos, J.C., Pagani, M., Sloan, L., Thomas, E. \& Billups, K., 2001 . Trends, rhythms, and aberrations in global climate $65 \mathrm{Ma}$ to present. Science 292: 686-693.

Zachos, J.C., Quinn, T.M. \& Salamy, S., 1996. High-resolution (104years) deep-sea foraminiferal stable isotope records of the Eocene-Oligocene climate transition. Paleoceanography 11(3): 251-266.

Ziegler, P.A., 1990. Geological Atlas of Western and Central Europe. 2nd edition. The Hague: Shell International Petroleum Maatschappij B.V., 239 pp. 